\title{
Why do informal markets remain informal: the role of tacit knowledge in an Indian footwear cluster
}

\author{
Yugank Goyal $^{1}$ (D) Klaus Heine $^{2}$
}

Accepted: 16 February 2021 / Published online: 8 April 2021

(C) The Author(s) 2021

\begin{abstract}
Why do informal markets resist formalizing, even when the gains of doing so outweigh its costs in the long run? While a number of responses to this question have been advanced, we discover that part of the reason could be located in the tacit knowledge (attributed to Polanyi, Hayek) embedded in the marketplace, on which market institutions run. This factor is not fully explored yet. Tacit (idiosyncratic, inarticulate, nonconscious) knowledge is acquired personally through experience and cannot be transferred or conveyed to anyone. This is the knowledge we use to act without knowing it in a propositional form. We present the case of one of India's largest informal footwear cluster, located in the city of Agra. We show that informal markets, hinged on tacit knowledge, cannot evolve easily and therefore may remain locked-in, despite external pressures or incentives to formalize. The study shows that efforts to overcome informality and reaping the benefits of formalized market structures cannot be done without taking cognizance of the sticky intangible knowledge on which these markets rest.
\end{abstract}

Keywords Informal markets · Path dependence $\cdot$ Trade credit - Tacit knowledge · Agra footwear cluster $\cdot$ Informal lending

JEL classification $\mathrm{B} 52 \cdot \mathrm{D} 83 \cdot \mathrm{E} 26 \cdot \mathrm{O} 17 \cdot \mathrm{O} 43 \cdot \mathrm{Z} 13$

Klaus Heine

heine@law.eur.nl

Yugank Goyal

ygoyal@jgu.edu.in; yugankgoyal@gmail.com

1 OP Jindal Global University, Sonipat Narela Road, Sonipat 131001, India

2 Erasmus School of Law, Erasmus University Rotterdam, Burgemeester Oudlaan 50, L7-29,

Postbus 1738 NL-3000DR, Rotterdam, the Netherlands 


\section{Introduction}

The tacit dimension of knowledge, largely attributed to Polanyi $(1958,1967)$ and Hayek (1952, 1967), has become a central category for understanding the role that knowledge plays in society. "Tacitness" means that large parts of knowledge cannot be conveyed explicitly and remain uncodified, as opposed to explicit knowledge which can be transferred or shared. Yet, if knowledge-based theories of growth (New Growth Theory) are to be considered seriously (Romer 1986; Grossman and Helpman 1994) then tacit knowledge becomes a 'problem', because knowledge which cannot be conveyed or transmitted, cannot be employed for accounting for growth in those frameworks. To put it differently, knowledge in a Romer-world can be re-used and distributed at no cost and must therefore become a source of increasing returns. But if one cannot transmit knowledge as easily, then there are limits to this modelling. Hence, it is no surprise that scholars of knowledge management put a lot of effort into the attempt to build frameworks that codify tacit knowledge in and between organizations and to make a connection with competitive advantage on the firm level, particularly employing a resource based view of the firm (e.g., Wernerfelt 1984; Barney 1991).

Shifting away from the intriguing problems of conceptualizing knowledge as an economic driving force on the firm and societal level, it can be observed that the socalled informal sector is largely unable to create adequate economic value for the people directly or indirectly depending on it. While businesses 'outside' the formal legal and regulatory net of jurisdictions employ more than $60 \%$ of the global workforce (86\% in Africa, 68\% in Asia and Pacific, 67\% in Arab states, 40\% in Americas and $25 \%$ in Europe and Central Asia) at the same time it is correlated with low levels of GDP (ILO 2018). A good part of research about the role of knowledge in the economy has not focused on those informal markets, which are not only the sites of labour vulnerability, low productivity and poverty, but which are also reluctant to change. Literature suggests that businesses in the informal sector are disadvantaged in comparison with their formal counterparts because of their general inefficiencies and high labour vulnerability (Fandl 2008). Yet, informal businesses seldom transform into formal business, and there is little consensus on why informal enterprises do not transform, if the gains from an improved level of institutionalization are potentially high. Why do many market clusters remain in their small networks transacting informally? Even when structural transformation of industries takes place through exogenous shocks, it often leaves many informal practices untouched (Harriss-White and Sinha 2007).

This contribution undertakes the attempt to shed more light on the nexus between the institutional rigidity of informal market clusters and tacit knowledge. To this end, we conducted a study in a very old informal business cluster in north India, namely the footwear cluster of Agra. In this study we extend the analysis of tacit knowledge beyond the formal firm and industry level by focusing on small-scale shoe manufacturers and their symbiosis with informal financial intermediaries. This will involve examining the notion of upgrading in informal clusters, something that has been largely ignored for local firms with no global linkages. More specifically, we look at one particular knowledge institution, namely that of trade credit.

In the centuries old Agra footwear cluster, trading of shoes takes place through credit. Poor shoemakers sell shoes on credit to the traders. To ensure a credible 
commitment in the relation between trader and shoemaker, the trader issues a paper slip to the shoemaker a so-called parchi which bears the outstanding amount, to be payable at the end of 3 months. The parchi is tradable in the market at a discount. The discount rate depends on the creditworthiness of the trader who issued the parchi. This means that if the trader is known to renege on his promise, his credit score will go down, the discount rate will increase and shoemakers will choose another trader whose discount rate is lower. Knowledge of creditworthiness and discount rates in this market is crucial for it to function. And this knowledge, being tacit in nature, is "sticky" and has resisted any institutional change in the market with respect to trade credit. In other words, we have to do with a market that emerged into a specific institutional configuration and has remained there unchanged for centuries, despite technical, economic and political disruptions around it. That leads to the hypothesis that tacit knowledge has a twofaced "Janus" effect in informal markets. On the one hand it makes those markets quite effective and profitable, but on the other hand it prevents the emergence of new institutional arrangements that might be necessary to maintain or enhance the competitiveness of the business in the long run.

The rest of the paper is structured as follows. In section 2, we refer to the relevant literature and make a link between informal markets and tacit knowledge. In Section 3, we describe the leather footwear industry in Agra, and its emergence, and we focus into the co-evolved trade credit institutions. In section 4, we explore the relation between the tacitness of knowledge and the institutional resistance to change. Section 5 concludes.

\section{Tacit knowledge and informal markets}

\subsection{The influence of tacit knowledge on organizations and business clusters}

There is a long-standing discourse on connections between knowledge attributes and various organizational forms that enhance the ability and competitiveness of organizations (see, for example, the contributions in Powell and DiMaggio 1991). But it was Polanyi $(1958,1967)$ who most explicitly stressed the importance of tacit knowledge for the advance of business and society. Variations of tacit knowledge are also found in the works of Hayek (1952, 1967), Ryle (1949) or Oakeshott (1975) to name but a few. Such knowledge cannot be easily transferred from one individual to another nor can it be aggregated for generalization. It rests in skills, experiences and ideas and cannot be easily expressed or codified, nor can it be aggregated either for generalization purposes or as an abstract concept.

A particularly influential linkage of tacit knowledge with organizational forms stems from Nelson and Winter's (1982) seminal study on evolutionary change. As an alternative to neoclassic growth models they interpret the firm as a collection of heterogeneous assets governed by 'routines', similar to genes in humans. They also illustrate how these routines are constructed hierarchically on the edifices of knowledge. This research agenda was further enhanced to build an interactor-view of the firm, against the replicator-view of routines (Hodgson and Knudsen 2004). This means, the organizational form becomes a by-product of its knowledge structure. For instance, low levels of hierarchy co-evolve with certain types of routines, which do not evolve in a hierarchical setup (Lazaric and Raybaut 2005). Or, certain organizational routines 
may propel and lift specific competences which are necessary to bring forth innovation. For example, the influential study by Nonaka and Takeuchi (1995) explores the use of tacit knowledge as a success factor within the industrial organization of the Japanese automotive and telecommunication industries.

While tacit knowledge is a valuable asset for building up competitiveness, not being able to valorise tacit knowledge can severely damage business activity and hinder efforts for organizational change (Stieglitz and Heine 2007, Heine and Rindfleisch 2013). This is stressed by von Hippel (1994) who points out that transferring or sharing codified knowledge is of little use, if the real need of an organization is that of accessing the tacit knowledge of its members. Similarly, Szulanski (2003) has introduced the idea of 'knowledge barrier', which is a critical factor for intra-organizational learning and initiating organizational change. It consequently has a visible bearing on an organization's character. These observations shift the focus from knowledge as such to the importance of tacit knowledge as the seedbed for entrepreneurial activity. It is the tacit, non-codifiable knowledge, clustered in individuals and firms in specific regions or communities of practice (Lave and Wenger 1991) that maintains the competitiveness of business (Cowan et al. 2000).

It is the advantage of knowledge-sharing that comes with co-location and clustering of various industrial units (Porter 2000). Even though economists have identified economies of scale and scope as important factors long ago (e.g., McCormick 1999; Oyeyinka 2017), it is more recently that scholars have shown that one of the great benefits of being in a cluster is the reduced costs of intra-cluster knowledge transfers (Sorenson 2003; Evers et al. 2010; Werker and Athreye 2004). Hence, a cluster's competitiveness, innovation and structure is crucially linked to knowledge sharing and spill-overs within the cluster (Werker and Athreye 2004; Polenske 2007). More specifically, scholars have linked tacit knowledge as an important factor for a cluster's performance, like innovation (Brusoni et al. 2005, Dwivedi and Arora 2019), knowledge dissemination (Pinch et al. 2003), collaboration between firms (Llerena and Ozman 2013), transfer of routines (Bagley 2019) and a host of other performance characteristics (Boschma and Lambooy 1999). In fact, the degree to which a cluster can become integrated with the economic system depends on whether or not several cluster attributes are conducive to learning (Parto 2008).

Another, empirically driven research stream, puts the focus on global value chains. Those studies engage with the knowledge-structure within and between organizations. Most of these studies analyse industries that are contained within either large firms or firms that have a global presence, like high-technology in general (Keeble and Wilkinson 1999; Lawson and Lorenz 1999), the computer industry (Baptista and Swann 1999) or biotechnology (Fontes 2005) and countless others, not necessarily high-tech industries (Sorenson 2003; Giuliani et al. 2005; Polenske 2007). Also, small and medium-sized industry clusters may build up global value chains, if the business organization has made the step to formal institutionalization, such as incorporation of the company, paying social security contributions, calculating the value added tax etc. (Bathelt et al. 2004; Tallman et al. 2004; Pietrobelli and Rabellotti 2011; Giuliani et al. 2005; Bazan and Navas-Alemán 2003). Those industries also produce statistical data which makes it relatively easy to test empirically hypotheses about the factors that foster the growth of the cluster, determine its innovative capacity or inform about the rent-distribution. As a result, small scale enterprises, which have no formal 
organizational structure and no global linkages in their value chain, have remained unexplored territory in cluster research.

\subsection{Informal market clusters and their resistance to formalisation}

All over the world informal clusters are sites of a huge lack of social security, inherent labour vulnerabilities and function largely outside the legal system. That is why they are often found at the centre of national or international reform projects, especially in developing countries. However, those efforts have not been overly successful. On the contrary, the informal sector has continued to expand in recent years. While the benefits of integrating into deeper value chains and of using economies of scale are evident, one would have thought that informal markets would shed their parochial attitude and assume formal structures to take part in the larger and connected economy (ILO 2018; Schneider and Enste 2013; Jütting and Laiglesia 2009). However, these markets are simply not breaking out of informality in the way one would have expected.

It is apparent that formal organizations have benefits in accessing finance from banks, become more productive by capital deepening and widening, can expand the scope of downstream markets, and can adopt best management practices (Djankov et al. 2002). Yet, informal markets often show little interest in growing out of their structure, even when the perceived benefits would outweigh the costs by far. Those markets are very agile in adapting to changing situational contexts, but they are rigid in their transformation into formal business. The ease with which they negotiate their space around their vulnerabilities is matched only by the reluctance to formalize. Surely, there is a cost of such transformation, but there is little doubt that the longterm gains from formalization have the potential to offset the short-term switching costs (Djankov et al. 2002).

Some of the reasons why informal markets remain informal are systemic, for instance, the formal economy is unable to absorb the available labour force, because of a growing population, persistently high levels of unemployment or declining real wages (ILO 2004, Becker 2004). Others have attributed the reasons to high tax burdens and complex administrative procedures for formal firms (Loayza 1996; Slemrod and Weber 2012; Schneider and Enste 2013) as well as the associated regulatory costs (de Soto 1989), a lack of credibility of public institutions (Dreher and Schneider 2009), inefficient contract enforcement and weak judiciaries (Loayza 1996), labour market dynamics related to labour law and minimum wages (Gallin 2001; Fortin et al. 1997) and other governmental issues which makes it unattractive to switch to formal business (Schneider 2011).

Most of these arguments view informality as an enterprise floating in a web of an economic infrastructure which forces it to remain informal. In other words, one is tempted to believe that the causes are mostly exogenous. Such a view takes a rather superficial view of how these markets work. Entrepreneurs are not always forced by 'necessity' into informal clusters, but they may be attracted by an 'opportunity' implied in informality (Williams and Nadin 2014).

Some studies have examined the impact of jurisdictional efforts to transform business from informality into formality (Djankov et al. 2002). The findings of these studies cause disillusion; most of the formalization initiatives failed (Olmedo and Murray 2002; Pérez Sainz 2005; Portes and Centeno 2006; Steel et al. 1997; Kappel 
and Ishengoma 2006; Dinkelman and Ranchhod 2012; Siggel 2010; Williams 2005). The failure of structural adjustment processes and accompanying reforms, particularly in Africa (Lall 1999), provided a reason to put more research effort into the inside perspective of industry clusters.

It is not true that informal business clusters lack any kind of structure (GuhaKhasnobis et al. 2006). It is well documented that businesses in informal markets are governed largely by private ordering and social norms (Ostrom 2015; Gambetta 1996; Ellickson 1991; Bernstein 1992; Macey 1997; Platteau 1994). Informal clusters function on trust-based linkages, repeated interactions, peer group pressure and endogenous enforcement, low information asymmetry through informal gossip, relational contracting and social networks. In fact, in recent decades, the literature on private ordering and its relation to economic development has grown significantly. McMillan and Woodruff (2002) study patterns in transition economies of erstwhile communist states and how informal mechanisms foster post-socialist development. Harriss-White (2010) explores the dynamics of informality in India and shows how such an economy is ordered and in which way social insecurity has become institutionalised. Through studying informal microfinance businesses in East Africa, Khavul et al. (2009) point to the importance of family and community ties in nurturing business. An interesting feature of informal markets is therefore, how informal ways of discovery processes become activated and how these processes are embedded in local competition. But the underlying mechanisms are not easy to decipher, because there aren't any written contracts, formal guarantees, sureties or a formal dispute resolution. Instead we find personal ties between people, proprietary knowledge and transparent ways of communication. But these features of informal markets make the relevance of tacit knowledge, for a better understanding of the evolution of those markets, even more important.

\subsection{The role of tacit knowledge in the making of informality}

Informal market clusters are hinged on persuasion, tradition and community consensus. The dealings of informal market participants are based on their 'being' in the market, where face value, verbal commitments, network linkages and caste/community based dynamics overpower those of written (if any) contractual arrangements. The underlying governance structures and implicit contractual arrangements are highly transactionspecific, relational and unique. The low degree of formalization of these arrangements also means that third parties (for example courts) cannot assess those and hence cannot enforce them. As a consequence, the relation, reputation and trust-based linkages between the involved parties become essential for completing transactions successfully. Thereby the routines and practices for maintaining the trust relation become a crucial part of the shared inventory of tacit knowledge. Because tacit knowledge is collected, processed, stored and retrieved through personal experience, individual human-capital investments become the epicentre of those polycentric informal market clusters. Indeed, the informal market workers learn by absorbing the tacit knowledge structures (Koops and Pilz 2019). In fact, reading Hayek's seminal paper about competition and information sharing reminds one of, and strongly connects to, the informal market clusters in Agra, Addis Ababa, Delhi, Sao Paulo or Jakarta. These informal markets build a sort of tacit knowledge commons similar to what Ostrom (1999) and Hess and Ostrom (2005) describe about self-governed communities. 
'[e]very individual... possesses unique information of which beneficial use... [is] based on... [the] knowledge of people of local conditions and of special circumstances... of the fleeting moment not known to others... The sort of knowledge with which I have been concerned is knowledge of the kind which by its nature cannot enter into statistics and therefore cannot be conveyed to any central authority and statistical form' (Hayek 1945: 251).

In fact, the reason for industrial clusters to emerge may not be driven by efficiency concerns as well as network effects in the first place, but by the need to access the common knowledge base and to make it a seedbed for innovation and growth options (Sorenson 2003; Langlois 2001). However, the type of informal clusters we are interested in, particularly in developing countries, have displayed little signs of innovation and growth over long periods of time (Caniels and Romijn 2004; Beerepoot 2008). In those cases clusters disseminate effectively tacit knowledge, but at the same time the specific organization of the market arrests innovation and growth.

To obtain a deeper insight into the conundrums of informal industry clusters we study the evolution of institutions in the Agra footwear cluster, and uncover the peculiar role of embedded tacit knowledge as a crucial factor for the persistence of informal institutions. To this end footwear clusters are appropriate sites, because of their long historical trajectory in which barely any innovation or institutional change took place.

We are not the first to study footwear clusters. Former studies about footwear clusters in developing countries have already pointed to the embedded nature of networks (Gebreeyesus and Mohnen 2013), the impact of trade liberalization on contract enforcement (Woodruff 1998; Rabellotti 1999) and rural industrialization (Huang et al. 2008). Most of those studies, if viewed through the lens of tacit knowledge, give raise to similar hypotheses as this paper. However, our focus is specifically on the analysis of trade credit. This allows us to study the effects of tacit knowledge in combination with informal institutions more thoroughly.

\section{Tacit knowledge in the Agra footwear cluster}

Agra is the most important centre for (leather) footwear manufacturing in India. The city contributes to $65 \%$ of the domestic footwear market and $35 \%$ of total footwear exports from India stem from Agra (Rawat 2013). About 35\% of the city's 1.7 million people are directly or indirectly involved with the footwear industry. For the background of these figures and given that the cluster has already been working for more than four centuries (Damodaran and Mansingh 2008), it is surprising that there are barely any scholarly industry studies about it (exceptions are the studies by Lynch (1969) and Knorringa (1994, 1999a, 1999b).

While Agra hosts large export houses and a considerable number of medium scale businesses, an overwhelming majority of labour is self-employed. According to some recent estimates, the industry is comprised of three categories of units. The large export houses would be around 15 in number, 30 medium scale enterprises, 150 small scale industrial units and around 10,000 micro-size units, with a total turn-over of around almost a quarter of a million pairs of shoes everyday (Singh 2019). 
In our study we focus on these 10,000 small units that sustain the largest number of families and which are run by poor self-employed artisans. In these household enterprises the skills are passed on through generations; there is no formal apprenticeship system. For centuries the artisans have been making footwear every day and sell it the next day in the largest trading bazaar of Agra, called Hing ki Mandi. This is a market that occupies an area of not more than $4 \mathrm{~km}^{2}$, but it hosts more than 500 trading and production units.

In the market, we are interested specifically in the institution of trade credit and how (a) the market is crucially hinged around it, (b) the tacit nature of knowledge that is needed to maintain the institution of trade credit, and (c) how the difficulty of formalizing knowledge prevents the cluster from escaping the shadow economy.

\subsection{Trade credit in the Agra cluster - the general pattern}

Hing Ki Mandi is a buzzling bazaar with hundreds of trading shops and units of traders. The artisans come to the market every day in the evening with their handmade shoes, usually a dozen pairs. The artisans predominantly belong either to the Hindu Jatav caste or Muslim communities, while the traders are mostly upper caste Hindu Punjabis. The standard routine at the shoe market is that traders purchase the shoes but do not pay upfront. They purchase them on credit, which is typically due after 3 months. The credit is then passed on from the trader to the retailer located elsewhere. Only when the retailer finally obtains money from the end-customer, will he pay the trader. And the trader will pay the shoemaker. The sale-purchase and money-transaction takes place without any written contract or securities.

Of course, many businesses around the world run on trade credit. But in the Agra shoe trade two unique problems exist that must be overcome. Firstly, how do traders signal a credible commitment to the shoemakers? In other words, what happens if the trader refuses to pay the shoemaker after 3 months? Secondly, typically trade credit is offered by someone whose cost of liquidity is relatively low. But unlike suppliers in other industries, Agra shoemakers are poor and suffer from a high cost of liquidity. They need cash today to buy raw materials for making tomorrow's shoes. How do they access credit for themselves if the trader only pays in 3 months?

The solution for this problem is the parchi, literally a paper-slip. When shoes are sold, the trader issues a parchi to the shoemaker which bears the trader's name, the amount and date on which this amount is payable. The parchi is signed by the trader and is offered as a promissory note. The trader will fulfil his obligation to whoever brings him the parchi on the due date. With sufficient trust in the market and sanctions (which will be discussed below), the parchi has the capacity to solve the problem of credible commitment. But the parchi solves also the problem of liquidity. Informal financial intermediaries have evolved in the market. So-called aadhatiyas buy the parchis at a discount. On the due date they go to the trader whose parchi they had purchased and claim the amount. The discount is their earning, the shoemaker gets his liquidity and the trader gets his credit. In many cases, the parchis act as currency as well, when shoemakers buy raw materials through a parchi-again at a discount. In that case the seller of the raw material takes of the role of the financial intermediary.

As a result there are three steps which make the trade relation work: 
Stage 1- The shoemaker gives shoes to the trader; the trader issues him a parchi worth 'p'.

Stage 2- The shoemaker sells a parchi to the aadhatiya; the aadhatiya buys it at a discount rate, $i$. He hands over the cash worth (1-i)p to the shoemaker.

Stage 3-At the time of maturity of the parchi, the aadhatiya gives the parchi back to the trader; the trader pays him $\mathrm{p}$ in cash.

The discount depends on the creditworthy reputation of the trader. If a trader is known to delay his payments or renege on his parchi promise, his discount rate is high compared to others which keep their promises. And since shoemakers want to sell the shoes to a trader with low discount rates, they will go to the most trustworthy ones. This means, if a trader wants to attract good shoemakers, he must be trustworthy and pay in time. This way without resorting to any legal means, the market has incentivized good behaviour and penalized breaches of trust.

It is worth noting that the discount rate does not depend on anything other than the traders' creditworthiness; not their caste, the value of the deal, or the quality of the shoes. Quality considerations only enter the picture when shoemakers with low quality footwear have to approach traders with high discount rates, because those with low discount rates have attracted the good quality shoemakers already in the first place. Overall, the market is very determined to ensure that only the creditworthiness affects the discount rate. In our interviews with traders we were told that on the day of payment, even if a dog comes with a parchi in its mouth, the trader will take the parchi and stick the cash in the dog's mouth. No trader wants to lower his discount rate. Thereby our primary survey revealed that the average discount rate is $14.1 \%$ per month, which is about $5 \%$ points higher than the interest rate of a bank loan for the same amount of credit. But shoemakers don't ask banks for credit. We will come back to this below.

Disputes between shoemakers and traders do happen. In those events the local association of shoe traders arbitrates. Those arbitration panels are staffed with senior traders from the community who have been successful in the shoe business. The panels mimic the rulings of formal courts and award damages and liquidation according to what appears to be feasible. Power relations may play a role in the courtroom, but the association has a keen interest in maintaining trust and fairness in the business. Hence, cases of association capture are rather rare and the panel decisions are equally enforced.

\subsection{Zooming in: The historical evolution of the parchi system}

The Hindu caste system forbids working with hides or leather for upper castes (Khare 1984). Hence, traditionally leather goods are fabricated mostly by Muslims and a particularly low ranked caste, the so-called Chamars. In Agra this caste is also known as Jatavs. Only those born as Chamars can 'occupy the status of shoemaker without breaking caste rules' (Lynch 1969). Because Agra has had always a huge Jatav population, as well as a big Muslim community (Imperial Gazetteer of India 1909), it is no coincidence that the Indian footwear cluster emerged there some centuries ago. The cluster's emergence received early support from the Mughal rulers (whose capital was Agra) during the 16th and 17th centuries. They were great patrons of art, craftsmanship and well-equipped warriors needing leather boots. This amalgam of 
supply and demand factors led to a considerable number of skilled footwear workers in Agra. Thereby Muslims were mostly the shop-owners and the workers were mostly Jatavs. The artisans centred around specific localities and the actual work used to happen in clusters of neighbourhoods - something we still see today.

When Agra was the capital of the North-Western Province during the midnineteenth century, the British rulers brought with them English designers and enhanced the skillset of the native artisans considerably. Around 1900 the first central shoe market was set up in Hing ki Mandi. The creation of this sort of meeting point facilitated the trade immensely, allowing wholesale traders to sit at one place where both shoemakers and other merchants could come together (Knorringa 1999b). This boost made Agra an important centre for English style men's shoes in the period between the two World Wars, and by the time when India became independent, its products were being exported to Iran, Iraq and the East Indies (Knorringa 1999b).

The partition of the Indian subcontinent in 1947 produced strong migration streams that changed the industrial structure irreversibly. The migrants from Pakistan to India were mostly Hindu-Punjabi in caste, while those migrating to Pakistan were mainly Muslims. It is estimated that about 14.5 million people were uprooted. Many migrant Punjabis settled in north India, including in the region of Agra. But because most of the affluent Muslims from Agra had left for Pakistan, the regional economy of Agra, including the shoe industry deteriorated (Knorringa 1999b). This situation changed when the newly arrived Punjabis noticed the artisan skills of Jatavs and poor Muslim shoemakers. They also noticed that there was a lack of market connectivity of shoemakers and unexploited opportunities for scaling up the shoe business by a low degree of division of labour. Many shoemakers tried to sell their own shoes, thereby wasting time in marketing instead of manufacturing shoes.

Hindu-Punjabis do not observe the strict forms of caste-based segregation. Trading in leather is not proscribed for them and the footwear trading in Agra caught their attention to make a living after they had migrated to Agra. Like anywhere in the world, migrant communities form cohesive groups that are driven by social norms which help the community to establish in the new situational context. In the beginning the Punjabis began working as commissioning agents for shoemakers. But quickly they learned that it is more profitable to buy the footwear and to sell it at places outside the traditional markets of Agra shoemakers. They began purchasing large quantities of shoes, thereby expanding and improving the system of credit (parchi).

The interviews suggest that the expansion of parchi has been a consequence of very limited access to bank credit at that time. Poor migrants had no securities on offer and the expected income stream was uncertain. Hence, they had to establish their own credit institution, working beyond the formal bank system. Over time, the Punjabi traders became rich and expanded the territory of their operations throughout India. The expansion of the business made it necessary to further improve the trade credit, especially to solve the latent liquidity problem. That was attained by an up-scaled role of the aadhatiyas which interlinked the shoemakers with the traders as credit intermediaries.

Perhaps the most interesting aspect of this evolution is the immutability of the market, specifically with respect to its trade credit institution. The Agra footwear cluster has existed in its small scale artisan industry structure for centuries. It has been absorbed into the religious and caste based perimeters. The English rule led to an 
expansion of the business but did not change the industry composition. Likewise, the partition of the subcontinent did not change the industry structure, although it led to an adaptation and professionalization of the incumbent credit institution - the parchi. But what began as a necessity for the Punjabi entrepreneurs (in the sense of Kuchař 2016) as a means for overcoming the denial of bank credit, is now frozen. The Agra shoe cluster has found its very own solution to deal with tacit knowledge and to activate it profitably for its members in a setting of informal institutions.

In the next section we discuss in more detail why despite several exogenous shocks, and despite a changing environment, the parchi system continues to act as a pivot for the entire cluster, but the parchi itself remains institutionally petrified. We will show that this can be traced back to the large amount of tacit knowledge on which the parchi system is based.

\section{Overcoming resistance to change: The tacit dimension}

\subsection{What is so tacit in the Hing ki Mandi?}

The knowledge about the creditworthiness of traders is the most crucial element of the intellectual and social infrastructure of the Hing ki Mandi market. It enables simultaneously the division of labour and cooperation between shoemakers, traders and intermediaries. Thereby the knowledge is created, dispersed and employed in a polycentric fashion (Ostrom 1999). Commitment within the system is sustained by the high degree of information symmetry in the market and the quick transfer of information within the social cohesive cluster. The information channels include gossiping, chats, rumours and informal gatherings in clubs, festivities or sports activities. The group cohesion becomes amplified because of the prevalent caste system. As suggested, historically, most traders are Punjabis by caste, while artisans and labourers are either Muslims or belong to the backward castes (Jatavs). The caste members have conjugal alliances and are members of the same clubs and associations in which they have their social contacts. Moreover, if one looks at their dwelling pattern, traders reside in specific locations in Agra, and hence they meet often during local social meetings. The Jatav or Muslim shoemakers live in their own settlements and after work they get together for local drinks.

This internal cohesion of groups sometimes pits one group against the other. The usual narrative among the traders is that the shoemakers are a lazy lot and they would prefer to spend their money for gambling and drinking. The shoemakers lament how traders exploit them, squeezing them out. Such group loyalty builds fast-moving narratives that only grease the exchange of information within the groups. And it the pieces of tacit knowledge transmitted in the gossiping that are reassembled as a complete picture of the fitness of one's business. It also enables dispute resolution to take place effectively. There is hardly any privacy because all activities at home, within the family, at weddings, visitors and guests, lost gambles and practically anything that has a material bearing on the business is known by anyone and everyone in the cluster.

Consequently, the discount rates of parchis go up if there is a news of non-payment or delayed payment, if people learn about consignments getting cancelled, or even if the wedding in a trader's family is not as lavish than expected. Hence, market 
participants' behaviour is extremely transparent, but can only be deciphered by embedded market participants. That explains why the local, informal arbitration (shoe trading associations) are very effective compared to regular courts, because a regular court could never decipher and assess the tacit information which is prevalent in the cluster.

For an outsider the information in the market cannot be accessed and assessed unless one becomes part of the market on a daily basis. This is what helps develop trust and which feeds into the building of the congenial human capital for dealing with the tacit knowledge. For that background it is no surprise that in all of our interviews we did not find a single first-generation trader or shoemaker. How would an alien person understand the market's internal functioning, future projections, family networks, interest rates in the housing market, weddings in the family, sizes of prospective orders and many other pieces of (even personal) knowledge that may have any bearing on the creditworthiness of the trader.

One may wonder, why does a trader not run away, taking with him all the credit he has accumulated? The answer lies in the fact that the footwear industry in Agra is largely characterized by family units. A trader's loans have always to be cleared by his sons and relatives, otherwise they will suffer from a bad reputation. The collective punishment frameworks, and the threat of future losses are so high that traders are effectively deterred from cheating. This sort of threat of sanctioning is similar to Greif's (2006) concept of multilateral punishment. Thereby it is tacit knowledge that discourages from engaging in activities which are socially undesirable. That means that tacit knowledge contains also moral values which are essential for the functioning of markets and does not only reflect on price signals or possibilities for arbitration. Obviously, tacit knowledge becomes in informal markets a much broader array of applications.

\subsection{Adaptation and resistance to change}

It is not true that everything about this market has remained as it was during the country's independence. Several things like technology or the ability to export have changed in recent decades. Yet, the parchi system and the relational contracting embedded in it, have remained immutable. By resisting institutional change, it has arrested the informal industry structure of the shoe cluster.

Research shows that when the necessary knowledge to do market transactions is moderately complex, socially proximate actors have the greatest advantage over distant actors in a marketplace (Sorenson et al. 2006). This fits precisely in the picture of what is happening in Agra, because deciphering market-relevant information for estimating the value of parchis is quite a complex matter. Our interviews conducted with families who have been in the trading and shoemaking business for more than four generations underscored this. Moreover, our interviews reveal that Lynch's (1969) half-a-century old description about the parchi system, the migrant Punjabi communities and the untouchable caste of Jatavs in Agra continues to hold. 'Today, instead of cash the Jatav frequently gets a credit slip payable after three months....since most of the producers work on a hand-to-mouth basis, they are forced either to sell the credit slip at a discount to a money lender, or they must buy new materials at a higher rate because they purchase on credit.' (Lynch 1969: 37). 
After independence in 1947 the next major shift for India took place in the early 1990s. It was the decline of the Soviet Union that triggered the liberalization of the Indian economy, including the opening of the Indian shoe market for imports and exports. The effect of trade liberalization was felt instantly. It led to a closure of a considerable number of production units in Agra. By 1996, as Knorringa notes (Knorringa 1999a) many firms had already closed down, because of the increasing international competition. Almost every shoemaking unit was affected in their customary manner of shoe production, and they had to lay off workers and concentrated more on domestic markets. The size of the Agra footwear cluster shrank, and its composition changed (Ibid., p. 1593-5).

Soon in this phase of surviving the gale from trade liberalization the Agra shoemakers began looking for new destinations for export by triggering new lines of products and marketing channels. The younger generation of shoemakers took the lead and improved the product quality. The shoe cluster was pushed to deliver higher quantities of shoes with a higher degree of standardization. The export units had to go through extensive audits and examination, and they fixed a good part of their production processes, mechanization, labour policies and business attitude. These changes led to an average improvement of the quality of shoes, an increased vertical cooperation with local suppliers of intermediate products, a higher speed of delivery, and more alternative export destinations besides the former Soviet Union; for instance now exports often go to Europe.

But while the market became more dynamic, the parchi system continued unabated. By some accounts in the interviews, it helped the shoemakers to extend credit lines and it gave access to liquidity when other possibilities as banks were not available due to economic crises.

Another impact hit the Agra cluster in the mid-2000s, when, as a result of trade liberalization and new rules on leather imports, and on FDI led Chinese importers and manufacturers to flood the Indian shoe market. Often the Chinese shoes were leatherlookalike and significantly cheaper. As a consequence, a considerable number of shoemakers had to give up their own business and to enter as an employee with some other business. But also many traders left the business. Many of these shoemakers and traders are now retired and the interviews with them revealed that this was a period when they pushed their college-going sons to look for jobs outside the shoe cluster. Those who remained, exhibited impressive agility. For example, they grudgingly adapted to produce synthetic leather shoes, or resorted to making leather shoes from waste leather from Kanpur, Kolkata and Chennai. This might be seen as some form of technological change triggered by market challenges.

But the parchi system remained as it is because the root of its functional channels is buried in the tacit knowledge. The impact that historical and technological developments haves had on the Agra shoe cluster, and the noticeable transformation in production process, relationships, customer base and quality, was possible because of their limited reliance on tacit knowledge.

Admittedly, from the interviews we learned that shoemakers have often felt that they are exploited through this system, particularly in times of distress. During the moments of crises illustrated above, the discount rates had spiked up, and hit the shoemakers economically. But they did not question the system as such or look for alternative forms of financing their business. There were also no alternatives offered to them. For 
instance, banks did not even attempt to finance the business of shoemakers. Banks, despite their lower cost of liquidity, are not able to offer credit to shoemakers because they lack the tacit knowledge which is necessary to estimate the credit default risk accurately and rather quickly. Accessing banks comes with high transaction costs. So, even if the interest rates are lower, effectively, they become unaffordable. Assessing the creditworthiness of shoemakers emerges from being an inclusive part of the market, rather than looking in the ledgers. Similarly, all kinds of small loans schemes as of the 1990 s by the government were hardly utilized by the shoemakers, because the transaction costs of accessing those by the shoemakers' schemes had become routinely high. In fact, the parchi simply eased the transactions, despite their higher interest. The same is true for microcredit, which has a much higher rate of interest than the discounts on parchi. That means, even new forms of credit cannot successfully compete with the incumbent parchi. The present central government has unleashed massive financial inclusion reforms, making it easy for people to open a bank account and access credit lines. Yet, shoemakers still prefer to sell the parchi to middleman, and traders still purchase shoes on credit, even when cash-purchases are cheaper.

\subsection{Up the hill: Higher levels of institutionalization}

The potential gains from a higher level of institutionalization could possibly outweigh the costs needed to make the shift. Indeed, if knowledge about the creditworthiness of traders was easily transferrable, a regular financial intermediary could emerge and exploit economies of scale in the credit business. Consider, for example, that the middlemen could come together and pool their risks in one fund, or, the government could initiate funding schemes that help poor artisans to receive loans at cheaper interest rates. One may also consider the vast possibilities of credit arbitrage. Parchis of trustworthy traders could be loaned out at a higher interest rate. New financial instruments could be invented, as for instance, parchis that become converted into collateralized debt obligations. An entire insurance industry might be carved out in the cluster, helping absorb some of the inherent risks in the system. Yet, no such institutional innovation takes place.

During our interviews we realized that people had indeed considered those institutional innovations but rejected them. A major hindrance was seen to be the difficulty of transferring relevant credit information ex ante from the shoemakers to the financial institution, but also to control and govern the credit relation between the parties ex post. As a result a financial institution from outside the cluster cannot adjust the default risk accurately and would require interest rates from the shoemakers which were structurally too high. Moreover, the loans would be processed with considerable delays whereas shoemakers and traders need cash instantly. Without economizing on the tacit knowledge of the market, financial intermediaries from outside the cluster cannot compete with the parchi.

In parallel to the resilience of the parchi system stands the unchanging nature of the caste system. Similarly, many minor things remain immutable, for instance labour relations, the spatial ordering of production units, the time and day on which trading and parchi-repayment takes place (payment dates are fixed to be every 5 days, starting on the 5 th of every month). As a consequence, for Agra Jatavs footwear is not simply an occupation for making a living, but 'It is a family affair and a way of life' (Lynch 
1969 , p. 7). And the way of life hasn't changed much over the last centuries. Obviously, taste, quality and production processes of shoes have visibly changed, but only within and through the parchi system, thereby recognising the informal rules of the cluster. It works like a social osmosis in which tacit knowledge interconnects cultural norms with technological skills and the customary financial routine. The difficulty of codifying it means that it is expensive to alter it and hence cheaper to follow it.

That is why little success was achieved when in the early 2000 s, the provincial government proposed a number of plans to enable more spaces where shoemaking in Agra could take place, complemented by an official program that was supposed to offer credit and skills training. In the end the ambitious plans were never realised. From our interviews we learned that those to whom the plan was addressed were not interested at all in making use of the new possibilities, because their community networks not only prescribed other routines for opening and running a business, but also the government plans did not fit into the web of tacit knowledge prevalent in the cluster.

In the Agra shoe cluster the discount rates associated with the parchis vary on the basis of dynamic information about traders' non-fulfilment of promises, delays in payment, exposure to high debt ratios, sustainability of business, or their liabilities outside the market (for example expensive marriages). The crucial factor to let the system work smoothly is thus the constant flow of information and its interpretation, but not in any recorded or coded manner, but purely by word-ofmouth, which makes it action driven, rather than principled or propositional. Factors that affect a trader's financial soundness are embedded in this day to day functioning. And knowledge about the trader, his dealings inside and outside the market, including, for example, the circumstances about a trader's personal life and that of his debtors and creditors is crucial. This sort of knowledge is extremely difficult to articulate in any conveyable form. That is also the reason, why more formalized ways of institutionalization cannot link to the parchi system and gradually change it. A formal system of providing financial capacity to the shoemakers would not refer to the tacit knowledge around. Hence, the specific form of tacit knowledge today prevalent in the cluster would be devalued. This is surely not in the interest of the people which have built their actual business on it. But the self-interest of people is only one reason that hinders taking the step to a higher degree of institutionalization; a different system of financial intermediation would also have to link to the caste system. While this is not a problem for an informal system as the parchi, it is a big problem for a formal system that seeks a higher degree of institutionalization and is acting independently from historical, cultural or religious prejudices. Moreover, a formal system would have to put large amounts of knowledge on paper, guarantee quick and equal access to justice and disregard customary rules.

\subsection{Going beyond Agra - some policy implications}

The lessons from this case are not particular to Agra alone. Patterns of tacit knowledge in trading can be observed in various kinds of informal markets which have long-held, community-based knowledge creation and dissemination. In fact, 
the Indian economy is dominantly characterized by geographical clustering of economic activity (Mukim 2012, Dwivedi and Arora 2019, Das 2005). Basole (2015) examines the weaving and textile cluster in Varanasi (India) and underscores the importance of tacit knowledge systems held through a culture of secrecy and family-based apprenticeships. Sundar (2018) explored India's artisanal fisheries and the interplay of tacit knowledge embedded in their networks of caste, kinship and village-communities. Basile (2011) studies the silk weaving industry in rural south India and hints at the importance of community attributes that affect institutional change as the region becomes more industrialized. Haynes (2012) in his remarkable exposition of historical emergence of artisanal business clusters through India's colonial history explores the design of tacit and community knowledge structures that have contributed to the continuation of these clusters even in situations of crises and rapid technological change. Of course, we do not claim that all business clusters always have their growth impeded due to tacit knowledge. We only suggest that they very well may, and therefore any policy measure merits careful scrutiny.

The impact of tacit knowledge in arresting institutional change is not limited to cluster-based upgrading alone. For instance, even as sex workers in Delhi begin getting independent and moving outside the red light areas, the need for the pimp has not declined, since they are the reservoirs of tacit knowledge with respect to clients, local gangs and negotiating with police (Goyal 2020). In fact, our anecdotal evidence suggests that trading in industries ranging from diamonds, medicines, steel scraps, groceries, trucking and even money laundering in India employs a credit rotation system as in Agra with considerable tacit knowledge embedded within. Even the coal mafia continues to infest some rich mines of India (notably in Dhanbad), despite the coal auction turning into an online eauction. The mafia still controls the labour force in the mines, and it can be interpreted to be doing so by its power through tacit knowledge about the workers, that emerged by historical ties of community and patronage (Goyal 2018).

Neglecting the role of tacit knowledge causes policy failure in a variety of settings (Bathelt et al. 2004, Lovell 2019). For instance, for several years, the government of India has been making ambitious policies for skills development in cluster-based small-scale enterprises without entirely satisfactory outcomes (Government of India 2016). Scholars have highlighted that this is often because of ignoring cultural and socio-political practices as well as historical identities based on social institutions (all constituting the tacit knowledge infrastructure) which are central to the process of change of attitude (Gooptu 2018). Research also indicates that employing tacit knowledge to design training for many informal workers can be particularly useful (Pilz et al. 2015). This is particularly true in the case of informal street vendors. Consider for instance, that the promulgation of the Street Vendors Act 2014, which sought to formalize the sector, was actively supported by the street vendors themselves. Yet, little success has been achieved because the legal construction of the act neglected the actual nature of how businesses are operated on the edifice of tacit knowledge. Similarly, the massive financial inclusion scheme of the government of India has not been able to curtail the informal savings practice of Indians; Goedecke et al. (2018) show that this is 
an effect of the cultural norms and social institutions, which in turn are indeed the vehicles to carry and sustain tacit knowledge.

\section{Conclusion}

In this contribution we have been interested in a better understanding of the role of tacit knowledge in informal markets. To this end we showed by the help of a realworld case that the presence of substantial, tacit knowledge in informal market clusters makes it exceedingly difficult to undertake institutional changes. While tacit knowledge unfolds a stabilizing function for participants in informal markets, it makes it impossible at the same time to attain a higher degree of formalization and to engage in more open competition. While our research focus as such is not entirely new, it closes a gap in the literature. Till now research on tacit knowledge has focused on big and medium scale enterprises in developed countries, and very little is understood about its role in small informal clusters. But it is exactly those smaller clusters that employ the vast majority of people in developing countries. Those clusters are often the subject of law reform projects. However, these projects mostly gloss over the tacit knowledge structures on which most clusters are built .

Our study may add a necessary building block for policy reforms, namely that of factoring crucial tacit knowledge in policy design.. But our study may also stimulate further research. Firstly, one cannot deny the possibilities that advanced information technology may bring to the business clusters. As people develop more web-based applications, one can imagine that there may be possibilities through user-generated data and algorithms to do predictive modelling about the creditworthiness of buyers/sellers. Secondly, one may have to study from a welfare perspective whether the enormous resilience of tacit knowledge in informal clusters is to be considered as a benefit for market participants or whether it nourishes a harmful institutional vegetation. Depending on the answer to this second question, policy makers have to decide how strongly they may have to intervene into historically grown institutions.

Open Access This article is licensed under a Creative Commons Attribution 4.0 International License, which permits use, sharing, adaptation, distribution and reproduction in any medium or format, as long as you give appropriate credit to the original author(s) and the source, provide a link to the Creative Commons licence, and indicate if changes were made. The images or other third party material in this article are included in the article's Creative Commons licence, unless indicated otherwise in a credit line to the material. If material is not included in the article's Creative Commons licence and your intended use is not permitted by statutory regulation or exceeds the permitted use, you will need to obtain permission directly from the copyright holder. To view a copy of this licence, visit http://creativecommons.org/licenses/by/4.0/.

\section{References}

Bagley MJ (2019) Networks geography and the survival of the firm. J Evol Econ 4:1173-1209 
Baptista R, Swann GP (1999) A comparison of clustering dynamics in the US and UK computer industries. J Evol Econ 9(3):373-399

Barney J (1991) Firm resources and sustained competitive advantage. J Manag 17(1):99-120

Basile E (2011) From the green revolution to industrial dispersal: informality and flexibility in an Industrial District for silk in rural South India. Eur J Dev Res 23(4):598-614

Basole A (2015) Informality and flexible specialization: apprenticeships and knowledge spillovers in an Indian silk weaving cluster. Dev Chang 47(1):157-187

Bathelt H, Malmberg A, Maskell P (2004) Clusters and knowledge: local buzz global pipelines and the process of knowledge creation. Prog Hum Geogr 28(1):31-56

Bazan L, Navas-Alemán L (2003) Upgrading in global and National Value Chains: recent challenges and opportunities for the Sinos Valley footwear cluster Brazil. In EADI's workshop "clusters and global value chains in the north and the third world" Novara, pp 30-31

Becker KF (2004) The informal economy: fact finding study (Vol. 76). Sida, Stockholm

Beerepoot N (2008) Diffusion of knowledge and skills through labour markets: evidence from the furniture cluster in metro Cebu (the Philippines). Entrepren Regional Dev 20(1):67-88

Bernstein L (1992) Opting out of the legal system: extra-legal contractual relations in the diamond industry. J Leg Stud 21(1):115-157

Boschma RA, Lambooy JG (1999) Evolutionary economics and economic geography. J Evol Econ 9(4):411429

Brusoni S, Marsili O, Salter A (2005) The role of codified sources of knowledge in innovation: empirical evidence from Dutch manufacturing. J Evol Econ 15(2):211-231

Caniels M, Romijn H (2004) Technological learning in small-enterprise clusters: conceptual framework and policy implications. In: Mani S, Romijn H (eds) Innovation learning and technological dynamism of developing countries. United Nations University Press, Tokyo, pp 158-177

Cowan R, David PA, Foray D (2000) The explicit economics of codification and tacitness. Ind Corp Chang 9: $211-253$

Damodaran S, Mansingh P (2008) Leather industry in India Centre for Education and Communication. Working Paper available at http://www.cec.india.org/libpdf/1437550410LeatherIndustryinIndia.pdf. Accessed 14 May 2020

Das K (2005) Indian Industrial Clusters. Ashgate Publishing, Farnham

De Soto H (1989) The other path: the invisible revolution in the third world. Harper and Row, New York

Dinkelman T, Ranchhod V (2012) Evidence on the impact of minimum wage laws in an informal sector: domestic workers in South Africa. J Dev Econ 99(1):27-45

Djankov S, Lieberman I, Mukherjee J, Nenova T (2002) Going informal: benefits and costs. World Bank

Dreher A, Schneider F (2009) Corruption and the shadow economy: an empirical analysis. Public Choice 144(2):215-277

Dwivedi A, Arora A (2019) Economic geography of innovation in India: an empirical investigation. Innovation and Development 10(3):395-412

Ellickson RC (1991) Order without law: how neighbors settle disputes. Harvard University Press, Cambridge

Evers HD, Gerke S, Menkhoff T (2010) Knowledge clusters and knowledge hubs: designing epistemic landscapes for development. J Knowl Manag 14(5):678-689

Fandl K (2008) The role of informal legal institutions in economic development. Fordham Int Law J 32(1):1-31

Fontes M (2005) Distant networking: the knowledge acquisition strategies of 'out-cluster' biotechnology firms. Eur Plan Stud 13(6):899-920

Fortin B, Marceau N, Savard L (1997) Taxation wage controls and the informal sector. J Public Econ 66(2): 293-312

Gallin D (2001) Propositions on trade unions and informal employment in times of globalisation. Antipode 33(3):531-549

Gambetta D (1996) The Sicilian mafia: the business of private protection. Harvard University Press, Oxford

Gebreeyesus M, Mohnen P (2013) Innovation performance and embeddedness in networks: evidence from the Ethiopian footwear cluster. World Dev 41:302-316

Giuliani E, Pietrobelli C, Rabellotti R (2005) Upgrading in global value chains: lessons from Latin American clusters. World Dev 33(4):549-573

Goedecke J, Guérin I, D'espallier B, Venkatasubramanian G (2018) Why do financial inclusion policies fail in mobilizing savings from the poor? Lessons from rural South India. Dev Policy Rev 36(S1):O201-O219

Gooptu N (2018) JSAD special issue on skill development in India. J South Asian Dev 13(3):241-248

Government of India (2016) Report of the committee for rationalization and optimization of the functioning of the sector skill councils. Ministry of Skill Development and Entrepreneurship, New Delhi

Goyal Y (2018) The coal mines mafia of India: the mirror of corporate power. Am J Econ Sociol 77(2):541-574 
Goyal Y (2020) Responsibilization through regulatory intermediaries in informal markets: examining the governance of prostitution in India. Regulation Governance 14(1):1-18

Greif A (2006) Institutions and the path to the modern economy: lessons from medieval trade. Cambridge University Press, Cambridge

Grossman GM, Helpman E (1994) Endogenous innovation in the theory of growth. J Econ Perspect 8(1):23-44

Guha-Khasnobis B, Kanbur R, Ostrom E (eds) (2006) Linking the formal and informal economy: concepts and policies. Oxford University Press, Oxford

Harriss-White B (2010) Work and wellbeing in informal economies: the regulative roles of institutions of identity and the state. World Dev 38(2):170-183

Harriss-White B, Sinha A (2007) Introduction. In: Harriss-White B, Sinha A (eds) Trade liberalization and India's informal economy. Oxford University Press, New Delhi

Hayek FA (1945) The use of knowledge in society. Am Econ Rev 35(4):519-530

Hayek FA (1952) The sensory order: an inquiry into the foundations of theoretical psychology. University of Chicago Press, Chicago

Hayek FA (1967) Studies in philosophy politics and economics. University of Chicago Press, Chicago

Haynes DE (2012) Small town capitalism in Western India: artisans merchants and the making of the informal economy 1870-1960 (Vol 20). Cambridge University Press, Cambridge

Heine K, Rindfleisch H (2013) Organizational Decline: A Synthesis of Insights from Organizational Ecology, Path Dependence and the Resource-Based View. J Organ Chang Manag 26(1):8-28

Hess C, Ostrom E (2005) Understanding knowledge as a commons: from theory to practice. MIT Press, Cambridge

Hodgson GM, Knudsen T (2004) The firm as an interactor: firms as vehicles for habits and routines. J Evol Econ 14(3):281-307

Huang Z, Zhang X, Zhu Y (2008) The role of clustering in rural industrialization: a case study of the footwear industry in Wenzhou. China Econ Rev 19(3):409-420

ILO (2004) Global employment trends. ILO, Geneva

ILO (2018) Women and Men in Informal Economy: A Statistical Picture. ILO, Geneva

Imperial Gazetteer of India (1909) Oxford Clarendon Press 1908-1931, vol 5, p 76 Available at http://dsal. uchicago.edu/reference/gazetteer/pager.html?objectid=DS405.1.I34_V05_085.gif Accessed 14 May 2020

Jütting JP, Laiglesia JR (2009) Is Informal Normal? Towards more and better jobs in developing countries. OECD, Paris, pp 19-35

Kappel RT, Ishengoma EK (2006) Economic growth and poverty: does formalisation of informal enterprises matter? German Institute of Global and Area Studies Working Paper no. 20

Keeble D, Wilkinson F (1999) Collective learning and knowledge development in the evolution of regional clusters of high technology SMEs in Europe. Reg Stud 33(4):295-303

Khare RS (1984) The untouchable as himself: ideology identity and pragmatism among the Lucknow Chamars. Cambridge University Press, Cambridge

Khavul S, Bruton GD, Wood E (2009) Informal family business in Africa. Entrepreneurship Theory and Practice 33(6):1219-1238

Knorringa P (1994) Lack of interaction between traders and producers in the Agra footwear cluster. In: Pedersen PO, Sverrisson A, van Dijk MP (eds) Flexible specialization-the dynamics of small-scale industries in the south. Intermediate Technology), London

Knorringa P (1999a) Agra: an old cluster facing the new competition. World Dev 27(9):1587-1604

Knorringa P (1999b) Artisan labour in the Agra footwear industry: continued informality and changing threats. Contrib Indian Sociol 33(1-2):303-328

Koops B, Pilz M (2019) Skills development in the informal economy: a case study from South India. Indian J Industrial Relations 54(4):580-600

Kuchař P (2016) Entrepreneurship and institutional change. J Evol Econ 26(2):349-379

Lall S (ed) (1999) The technological response to import liberalization in sub-Saharan Africa. Macmillan, London

Langlois RN (2001) Knowledge consumption and endogenous growth. J Evol Econ 11(1):77-93

Lave J, Wenger E (1991) Situated learning: legitimate peripheral participation. Cambridge University Press, Cambridge

Lawson C, Lorenz E (1999) Collective learning tacit knowledge and regional innovative capacity. Reg Stud 33(4):305-317

Lazaric N, Raybaut A (2005) Knowledge hierarchy and the selection of routines: an interpretative model with group interactions. J Evol Econ 15(4):393-421

Llerena P, Ozman M (2013) Networks irreversibility and knowledge creation. J Evol Econ 23(2):431-453 
Loayza NV (1996) The economics of the informal sector: a simple model and some empirical evidence from Latin America. Carnegie-Rochester Confer Series Public Policy 45:129-162

Lovell H (2019) Policy failure Mobilities. Prog Hum Geogr 43(1):46-63

Lynch OM (1969) The politics of Untouchability. Columbia University Press, New York

Macey JR (1997) Public and private ordering and the production of legitimate and illegitimate legal rules. Cornell Law Rev 82:1123-1149

McCormick D (1999) African enterprise clusters and industrialization: theory and reality. World Dev 27(9): $1531-1551$

McMillan J, Woodruff C (2002) The central role of entrepreneurs in transition economies. J Econ Perspect 16(3):153-170

Mukim M (2012) Does agglomeration boost innovation? An econometric evaluation. Spat Econ Anal 7(3): 357-380

Nelson RR, Winter SG (1982) An Evolutionary Theory of Economic Change. Harvard University Press, Cambridge

Nonaka I, Takeuchi H (1995) The knowledge-creating company: How Japanese companies create the dynamics of innovation. Oxford University Press, New York

Oakeshott M (1975) On human conduct (Vol 117). Clarendon Press, Oxford, Oxford

Olmedo C, Murray MJ (2002) The formalization of informal/precarious labor in contemporary Argentina. Int Sociol 17(3):421-443

Ostrom E (1990) Governing the commons:\&nbsp; evolution of institutions for collective action. Cambridge University Press, New York

Ostrom V (1999) Polycentricity (part 1). In: Polycentricity and Local Public Economies: Readings from the workshop in political theory and policy analysis. University of Michigan Press, Ann Arbor

Oyeyinka O (2017) Industrial clusters institutions and poverty in Nigeria in industrial clusters institutions and poverty in Nigeria. Springer, Cham

Parto S (2008) Innovation and economic activity: an institutional analysis of the role of clusters in industrializing economies. J Econ Issues 42(4):1005-1030

Pérez Sainz JP (2005) Labor exclusion in Latin America: old and new tendencies. In: Kudva N, Beneria L (eds) Rethinking Informalization. Cornell University Open Access Repository, Ithaca

Pietrobelli C, Rabellotti R (2011) Global value chains meet innovation systems: are there learning opportunities for developing countries? World Dev 39(7):1261-1269

Pilz M, Uma G, Venkatram R (2015) Skills development in the informal sector in India: the case of street food vendors. Int Rev Educ 61(2):191-209

Pinch S, Henry N, Jenkins M, Tallman S (2003) From 'industrial districts' to 'knowledge clusters': a model of knowledge dissemination and competitive advantage in industrial agglomerations. J Econ Geogr 3(4): 373-388

Platteau JP (1994) Behind the market stage where real societies exist-part I: the role of public and private order institutions. J Dev Stud 30(3):533-577

Polanyi M (1958) Personal knowledge. University of Chicago Press, Chicago

Polanyi M (1967) The tacit dimension. University of Chicago Press, Chicago

Polenske KR (ed) (2007) The economic geography of innovation. Cambridge University Press, Cambridge

Porter ME (2000) Location competition and economic development: local clusters in a global economy. Econ Dev Q 14(1):15-34

Portes A, Centeno M (2006) In: Fernandez-Kelly P, Sheffner J (eds) The informal economy in the shadow of the state. Out of the shadows: the informal economy and political movements in Latin America Princeton University press, Princeton, pp 23-49

Powell W, DiMaggio P (eds) (1991) The new institutionalism in organizational analysis. University of Chicago Press, Chicago

Rabellotti R (1999) Recovery of a Mexican cluster: devaluation bonanza or collective efficiency? World Dev 27(9):1571-1585

Rawat VS (2013) Agra footwear industry mulling consortium concept to take on China. Business standard 21 January. Available at https://www.business-standard.com/article/companies/agra-footwear-industrymulling-consortium-concept-to-take-on-china-111091400066_1.html Accessed 14 May 2020

Romer PM (1986) Increasing returns and long-run growth. J Polit Econ 94:1002-1037

Ryle G (1949) The concept of mind. Barnes \& Noble, New York

Schneider F (2011) The shadow economy and shadow economy labor force: what do we (not) know? Discussion paper series number 5769/Forschungsinstitut zur Zukunft der Arbeit 2011

Schneider F, Enste DH (2013) The shadow economy: an international survey. Cambridge University Press, Cambridge 
Siggel E (2010) The Indian informal sector: the impact of globalization and reforms. Int Labor Rev 149(1):93-105 Singh A (2019) Agra's footwear industries: a heritage that contributes to India's economy. SME Futures, 7 January

Slemrod J, Weber C (2012) Evidence of the invisible: toward a credibility revolution in the empirical analysis of tax evasion and the informal economy. Int Tax Public Financ 19(1):25-53

Sorenson O (2003) Social networks and industrial geography. J Evol Econ 13(5):513-527

Sorenson O, Rivkin JW, Fleming L (2006) Complexity networks and knowledge flow. Res Policy 35(7):994-1017

Steel WF, Aryeetey E, Hettige H, Nissanke M (1997) Informal financial markets under liberalization in four African countries. World Dev 25(5):817-830

Stieglitz N, Heine K (2007) Innovations and the role of complementarities in a strategic theory of the firm. Strateg Manag J 28(1):1-15

Sundar A (2018) Skills for work and the work of skills: community labour and technological change in India's artisanal fisheries. J South Asian Dev 13(3):272-292

Szulanski G (2003) Sticky Knowledge: Barriers to knowing the firm. Sage, London

Tallman S, Jenkins M, Henry N, Pinch S (2004) Knowledge clusters and competitive advantage. Acad Manag Rev 29(2):258-271

Von Hippel E (1994) "Sticky information" and the locus of problem solving: implications for innovation. Manag Sci 40(4):429-439

Werker C, Athreye S (2004) Marshall's disciples: knowledge and innovation driving regional economic development and growth. J Evol Econ 14(5):505-523

Wernerfelt B (1984) A resource-based view of the firm. Strateg Manag J 5(2):171-180

Williams CC (2005) Formalising the informal economy: the case for local initiatives. Local Gov Stud 31(3): 335-349

Williams CC, Nadin S (2014) Facilitating the formalisation of entrepreneurs in the informal economy towards a variegated policy approach. J Entrepreneurship Public Policy 3(1):33-48

Woodruff C (1998) Contract enforcement and trade liberalization in Mexico's footwear industry. World Dev 26(6):979-991

Publisher's note Springer Nature remains neutral with regard to jurisdictional claims in published maps and institutional affiliations. 